\title{
防災・隇災分野における 計算機シミュレーション
}

樫山和男

\section{1.はじめに}

日本列島は、毎年のように大規模な自然災害 に見舞われている。これは、日本列島の持つ地 形学的および気象学的な特徵に起因している。 日本列島は、地形学的に急峻であり四方が海に 囲まれ、複数の地殼プレートが複雑にぶつかり 合う場所に位置しているため、地震・津波・火 山・土砂災害等が頻発する。また、気象学的に は東アジアモンスーン地帯に位置し、台風等に よる豪雨災害が頻発する。図1は、自然災害を 受けやすい（被桨可能性）国別分布を示したも のであり、数值は毎年自然災害に襲われる可能 性のある人数を総人口比で表したものである。 この図からも明らかのように、日本をはじめと するアジア地域は世界の中でも最も自然災害を 受けやすい地域となっていることがわかる。と りわけ、日本はその数值が $40 \%$ と先進国の中で 最も高い数值となっている。

防災・減災に関する研究分野は、対象とする 空間および時間スケールが大きいことが特徴で

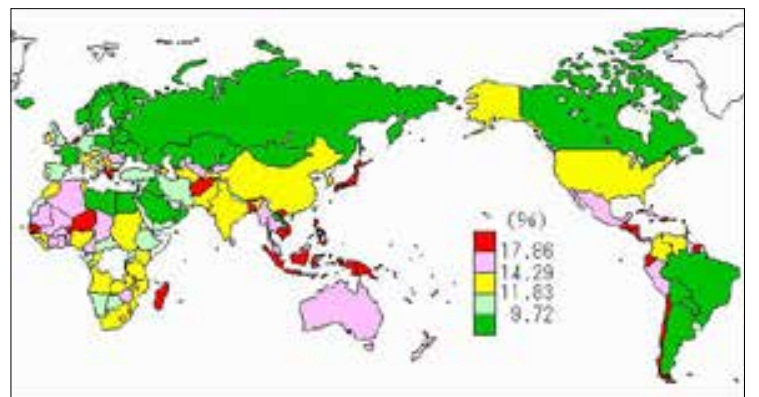

図 1 自然災害に遭いやすい国

(国連大学, World Risk Report 2011 )
あり、そのため相似則や安全性の観点から実験 力学的アプローチが困難となる場合が多く、計 算力学的アプローチがその威力を大いに発揮す る分野の一つである ${ }^{2)}$ 。自然災害を引き起こす に至る物理的な過程および発生してからの挙動 は、様々な物理現象が複雑に絡み合うマルチ フィジックス問題であり、また同時に、全体的 な挙動は局所的な挙動に左右されるマルチス ケール問題でもある。従って、自然災害を高精 度に予測するためには、マルチフィジックス・ マルチスケールに基づく現象のモデル化を行う ことが重要になる。この現象のモデル化につい ては、災害の種別ごとに異なるため、本稿では、 防災・減災に関する計算機シミュレーションに おいて共通する計算技術について着目し、その 現状と課題について述べる。

\section{2. 防災・減災分野における 計算機シミュレーションの特徵}

防災・減災に関するシミュレーションは、近 年の飛躍的なコンピュータの進歩により急速な 発展と拡がりを見せている。この分野のシミュ レーションは緊急性と公共性が高いため、シ ミュレーションにおいては、それを高精度かつ 高速に実行し、その結果を誰もが容易に理解で きるように可視化することが求められる。

本章では、これらを実現するための計算技術 に関するキーワードについて述べる。 
まず、高精度に解析するためには、対象とす る自然災害の物理現象をモデル化した支配方程 式（偏微分方程式）を、適切な初期条件および 境界条件をもとに、適切な離散化解析手法（有 限差分法、有限体積法、有限要素法など）によ り解くことは言うまでもない。計算技術に着目 した場合には、ユーザ側で解析の都度作成する 解析対象の幾何学的形状を表現した形状モデリ ングとそれを用いたメッシュ生成の品質が重要 となる（以下では形状モデルとメッシュ生成を 含めてモデリングと称する)。これを実現する ためのキーワードが「GIS/CAD/BIMデータを 用いたモデリング」である。防災・減災のシミュ レーションの場合には構造物以外に、地形や地 質のデータを正確にモデリングすることが大変 重要となる。

次に、高速に計算する点については、防災・ 減災に関するシミュレーションは空間のみなら ず時間スケールも大きいため、一般に超大規模 計算になる。この超大規模計算を高速に実現す るためのキーワードが「大規模並列計算」であ る。並列計算は今日では一般的になった計算技 術であるが、大規模問題に対して効率の高い並 列計算を行うためはハードウェアの特徴を活か した工夫が必要となる。

最後に、シミュレーション結果を分かり易く 可視化する点であるが、防災・減災対策を講じ る上では、設計者間のみならず地域住民の理解 と合意を得ることが重要であり、可視化の果た す役割は大きい。これを実現するキーワードと
して「バーチャルリアリティ技術を用いた可視 化」がある。

\section{3. 防災・減災に関する計算技術}

本章では、前章で述べた計算技術に関する三 つのキーワードの現状と課題について述べる。

\subsection{GIS/CAD/BIMを用いたモデリング}

防災・減災に関する計算機シミュレーション を高精度に行うためには、地形・地質・構造物 を正確に表現した三次元モデルを作成すること が重要である。また、それらに対する属性デー 夕（材料定数、透水係数、粗度係数など）を正 確に入力する必要がある。これらの事前過程(プ リ・プロセス）は計算機シミュレーションにお いて最も手間と時間を要するものであり、迅速 かつ正確に行うことが要求されている。現在で は、近年整備・普及の著しいGIS（Geographic Information System）データ（国土地理院発行 の数值地図など3)）の利用により、正確な地形 のモデル化が行えるようになり、それと構造 物 のCAD (Computer Aided Design) データ を組み合わせることで、地形と構造物が一体と なった形状モデルを比較的簡便に作成すること が可能となっている。また、政令指定都市など の大都市では、それらが一体となった形状モデ ルデータを持つ 3 次元数值地図も整備されてい る。図 2 はGIS/CADデータを用いて作成した モデルを用いて津波のシミュレーションを行っ 
た事例である ${ }^{4)}$ 。図より、微地形や構造物を正 確に表現した形状モデルとなっていることが分 かる。

しかし、解析に必要な属性デー夕については GIS/CADデータには含まれていないため、別 途、異なるデー夕を用いて準備することにな る。その際に、属性データとメッシュデータと を対応させる必要があり、この点の煩雑さは依 然として解消されていない。この問題点を解 消するためのものとして、現在BIM（Building Information Modeling) ${ }^{5)}$ データが注目を集め ている。BIMデータとは、建物の形状データの 他に、建物の設計、施工、維持管理に関わる必 要な属性を定義し、それらを保持するデー夕群 である。例えば、各部材には 3 次元形状の他に 部材の種類や名称、材質などの属性情報が入力 されている。なお、土木構造物に対して同様の 属性を保持しているデータ群は特にCIM（Civil Information Modeling) データと呼ばれている。 これらのデータを用いることにより、形状デー 夕とシミュレーションに必要な属性デー夕を

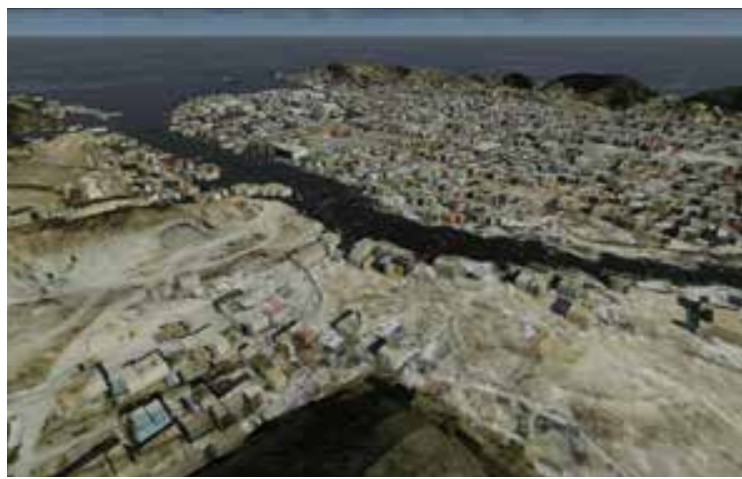

図2 GIS/CADデータを用いた 津波シミュレーションの可視化事例 ${ }^{4)}$

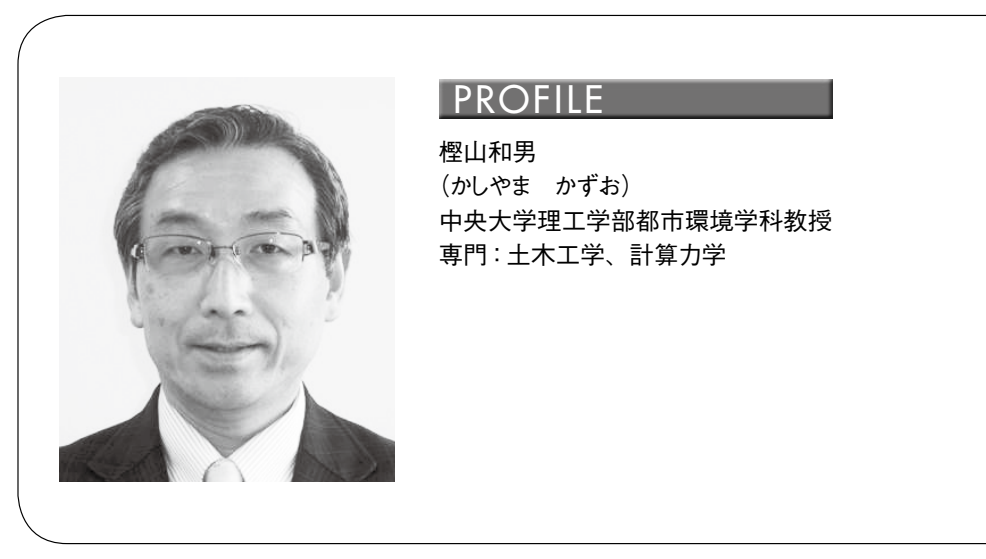

一括で入力可能となるため、モデリングがより 簡便かつ正確に行うことが可能になることが期 待されている。しかし、BIM/CIMデータの整 備は始まったばかりであり、今後はBIM/CIM デー夕の普及・整備が望まれる。また、解析に 必要な属性情報は、解析の種類・目的によって も異なるため、どのようなデータを実装すべき か等の基準作りも課題である。

\section{2 大規模並列計算}

防災・環境シミュレーションは一般に大規 模計算となり、かつ、緊急性を要する場合が多 いのが特徵である。この点については、大規模 計算を高速に処理可能な並列計算法が有効に用 いられている。並列計算の方法としては、プ ロセスを並列処理する OpenMP（Open MultiProcessing) と解析領域を分割して領域ごとに並 列処理するMPI (Message Passing Interface) に大別される ${ }^{6)}$ 。並列計算手法は使用する並列 計算機のハードウェアに依存しており、すべて のプロセッサーがメモリを共同で使用する共有 メモリ型の場合にはOpenMPおよびMPIが使 用可能であり、すべてのプロセッサーが個別に 
メモリを持っている分散メモリ型の場合には MPIの使用が可能である。また、大規模な並列 計算システムでは、一般に共有分散メモリ型と なるため、この場合には、MPIのみを使用する 並列計算と、ノード内の並列をOpenMPで行 い、ード間の通信にMPIを用いるハイブリッ ドな並列計算が適用可能である。なお、超大規 模な計算では、計算に必要なノード数が多くな ることから MPIまたはOpenMP と MPIを併用 する手法が用いられている。

また、近年では、グラフィック処理に用い られるGPU（Graphics Processing Unit）の超 高速な処理速度に着目し、それを超大規模計 算に用いる GPGPU（General Purpose Graphics Processing Unit）計算 ${ }^{7)}$ が注目を集め、防災・ 減災のシミュレーションにも用いられている。 GPGPUは、構造格子系のシミュレーションで はCPUを用いる手法に比べて驚異的なスピー ドアップとなることが報告されている。しかし、 非構造系の解析手法への適用の効果は低く、こ の点は課題の一つになっている。

\section{3 バーチャルリアリティ技術を用いた可視化}

バーチャルリアリティ（virtual reality：以後 VR）とは、みかけや形は原物そのものではな いが、本質的あるいは効果として現実であり原 物である環境をさす ${ }^{8)}$ 。VR技術において基本 的で重要なものは、VR空間内で立体視を実現 する技術であり、それにより利用者は対象物を 三次元的に、正確かつ直感的に把握することが
可能となる。

立体視の方法としては、両眼視差を利用 する方法が一般的である。すなわち、左右両 眼の映像を作成し、左目には左目のみの映像 を、右目には右目のみの映像が入るようにす ることにより立体視を実現する方法である。 また、立体視を実現する装置としては、HMD (Head Mounted Display) とCAVE (CAVE Automatic Virtual Environment）がある。各 装置にはそれぞれ長所・短所があるが、防災・ 減災のシミュレーションでは、CAVEの利用事 例が多い。CAVEはHMDに比べて、実寸感覚 と高い没入感が得られるとともに複数人が同じ VR空間を共有可能であり、対象物のミクロ・ マクロ部分を同時に見ることが可能である ${ }^{9)}$ 。

罒3は、CAVE内のVR空間においてシステ ム利用者が、津波が護岸を乗り越えていく様子 を実スケールによる立体視により観察している 様子である ${ }^{9)}$ 。立体視に基づく可視化により、 利用者はあたかもその場所で津波に遭遇する感 覚を実感でき、津波の三次元的な現象の把握を 正確に行うことが可能となる。また、立体的な

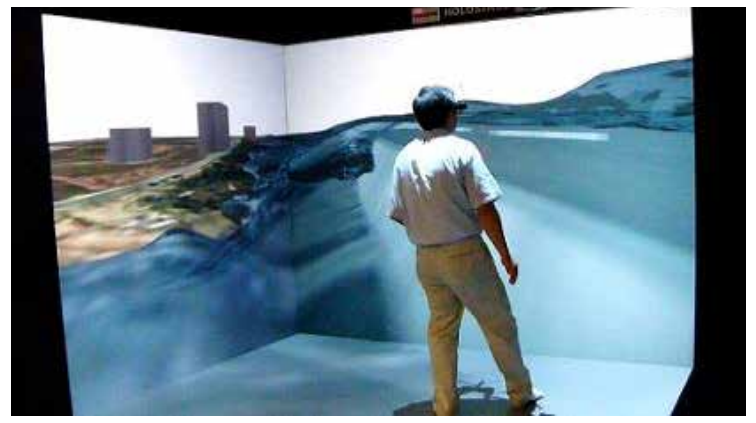

図3 VR空間で津波を観察している様子9 
視覚情報に加えて聴覚情報を付加することによ りシステム利用者は実際に津波が迫ってくるよ うな臨場感を得ることが可能となる。また利用 者は、VR空間内を自由に移動が可能であるた め、様々な視点から数值シミュレーション結果 の可視化映像を観察することが可能であり、現 象の全体把握と同時に詳細把握も迅速かつ容易 に行うことができる。

VRは、3次元情報を多人数で情報（感覚） を共有することを可能にするため、防災・減災 対策等の計画・設計段階における、計画者・設 計者間あるいは住民との合意形成を実現するう えで有効な方法と言える。さらにVRの応用と して、現実環境に情報を付加して現実環境を拡 張する拡張現実（Augmented Reality:AR）や、 現実空間と仮想空間を混合した空間を構築する 複合現実（Mixed Reality：MR）なども注目を 集めており ${ }^{10)}$ 、今後の動向が注目される。

\section{4. おわりに}

本稿では、防災・減災に関する計算機シミュ レーションにおける現状と課題について、計算 技術に着目して述べた。「はじめに」でも述べ たように、この分野の特徵は対象とする空間お よび時間スケールが大きいことが特徴であり、 そのため相似則や安全性等の観点から計算力学 的アプローチがその威力を大いに発揮する分 野の一つである。その一方で、計算結果の検証 と妥当性の確認が困難な分野でもある。このた
め、防災・減災シミュレーション分野の V\&V （Verification and Validation）の普及と発展が 期待されるところである。この点については、 土木学会内に委員会が設けられて活動を開始し ており、その成果に期待したい。

また、防災・減災を実現するためには、先の 東日本大震災による津波災害や大島や広島での 土石流災害等により明らかになったようにハー ド的な対策のみでは限界があり、ソフト的な対 策として早期避難が大変重要となる。このため、 人的被害の予測と軽減に資する避難行動シミュ レーションの重要性が認識されており、人間行 動分析に基づく当該分野の進歩と発展にも期待 したい。

\section{参考文献}

1）国連大学, World Risk Report 2011, http://www.ehs.unu. edu/file/get/9018

2）特集 防災・減災, 計算工学（日本計算工学会誌）, Vol.19, No.1, pp.2-22, 2014.

3）国土地理院 http://www.gsi.go.jp/chizujoho/ chizujoho40028.html

4）岩塚雄大、古牧大樹、西畑剛、川辺赳史、樫山和男：地域 防災教育のための3 次元津波浸水解析とその可視化に関す る研究, 土木情報学シンポジウム講演集, Vol.39, 2014 (投 稿中）。

5）特集 BIM, 計算工学（日本計算工学会誌）, Vol.19, No.2, pp.2-22, 2014.

6）樫山和男、西村直志、牛島省、並列計算法入門、計算力 学レクチャーシリーズ3、丸善、2003.

7) 特集 計算工学でのGPUコンピューティング, 計算工学(日 本計算工学会誌）, Vol.15, No.4, pp.4-23, 2010.

8）廣瀬通孝：バーチャルリアリティ、産業図書、1993.

9）樫山和男, VR技術の進歩とその3次元数值シミュレーショ ンへの応用, 土木技術, Vol.68, No.7, 53-58, 2013.

10）特集VR/MR/AR, JACIC情報103（日本建設情報総合セン ター) , Vol.26, No.3, pp.4-79, 2011. 